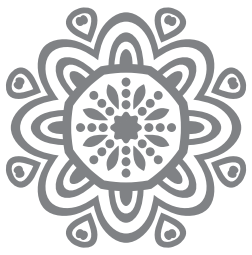

\title{
Konsepsi Pendidikan Anak Berbasis Fitrah dalam Perspektif al-Qur'an
}

\author{
Aas Siti Sholichah \\ Mahasiswi Program Doktoral Pendidikan Berbasis al-Quran Institut PTIQ Jakarta \\ Email: shalichah@gmail.com \\ hp: 08159328125
}

\begin{abstract}
Abstrak: Anak adalah anugerah tak ternilai bagi orang tua. Kebahagiaan orang tua adalah ketika mendapatkan buah hati sesuai yang diharapkan, untuk itu orang tua mempunyai tanggung jawab besar untuk mendidik dan membesarkan anak-anak sampai dewasa. Mendidik bukan hanya sekedar memberikan pengetahuan dan materi pembelajaran. Mendidik anak-anak adalah memfokuskan segala sikap dan tingkah laku agar menjadi tauladan bagi anak-anak. Sebagai landasan mendidik buah hati Al-Qur'an secara mendalam memberikan tuntunan melalui ayat-ayat Al-Qur'an yang di dalamnya menjelaskan bagaimana cara mendidik dan mempersiapkan anak-anak agar kelak siap untuk hidup dan mengarungi kehidupan di masyarakat. Mendidik secara fitrah merupakan landasan awal yang ditawarkan Al-Qur'an dalam mendidik anak. Karena dengan landasan fitrah anak memiliki potensi keimanan sejak dalam kandungan, dibekali pendengaran, penglihatan dan hati untuk dapat berfikir dan belajar, memiliki kemampuan bakat yang luar biasa dan beragam yang akan menjadi potensi bagi kelangsungan hidup anak juga dengan fitrah yang dimiliki anak dapat hidup bersinergi dengan lingkungan sekitar dan dapat menjaga dan melestarikan alam ini, karena fitrah alam sudah tertanam dengan baik. Untuk itu sebagai orang tua keharusan untuk mengapresiasi dan memotifasi setiap fitrah yang sudah ada agar dapat tumbuh dan berkembang dan anak dapat hidup dengan menikmati potensi yang dimiliki.
\end{abstract}

Kata kunci: Al-Quran, Fitrah, Pendidikan. 


\section{A. Diskursus Pendidikan Anak}

Ki Hajar Dewantara mendefinisikan pendidikan yaitu menuntun segala kekuatan kodrat yang ada pada anak-anak agar mereka sebagai manusia dan sebagai anggota masyarakat dapatlah mencapai kemaslahatan dan kebahagiaan setinggi-tingginya. ${ }^{1}$ Dalam makna yang lebih luas, ungkapan Ki Hajar Dewantara mengenai pendidikan juga dapat di definisikan sebagai penuntun, pembimbing, dan petunjuk arah bagi para peserta didik agar mereka dapat tumbuh menjadi dewasa sesuai dengan potensi dan konsep diri yang tertanam dalam diri sebenarnya. ${ }^{2}$

Dalam pengertian di atas pendidikan adalah upaya memberikan pemahaman, tauladan, bimbingan yang dilakukan secara konsisten dan membutuhkan waktu dan kesungguhan dengan mengembangkan potensi yang tertanam sejak lahir untuk mendapatkan kebahagiaan dan kemaslahatan. Untuk itu upaya yang dilakukan dalam konsepsi pendidikan tersebut harus dilakukan bersama-sama antara orang tua, sekolah dan masyarakat.

Upaya pemberian tauladan dan pengetahuan merupakan tugas bersama yang harus dilakukan baik oleh orang tua, pengajar maupun masyarakat, karena sinergitas ketiganya akan menghasilkan sikap mendidik yang dapat memberikan kekuatan karakter terhadap anak. Hal ini sebagaimana definisi pendidikan menurut Edgar Dalle yang menjelaskan pendidikan sebagai usaha sadar yang dilakukan oleh keluarga, masyarakat, dan pemerintah melalui kegiatan bimbingan, pengajaran, dan latihan yang berlangsung di sekolah dan di luar sekolah sepanjang hayat untuk mempersiapkan peserta didik agar dapat memainkan peranan dalam berbagai lingkungan hidup secara tetap untuk masa yang akan datang. ${ }^{3}$

Berbagai hakikat definisi pendidikan di atas, sejalan dengan fungsi pendidikan menurut pasal 1 Undang-undang Sistem Pendidikan Nasional Nomor 20 Tahun 2003, fungsi pendidikan adalah mengembangkan kemampuan dan membentuk watak serta peradaban bangsa yang bermartabat dalam rangka mencerdaskan kehidupan bangsa. ${ }^{4}$ Upaya yang dilakukan dalam menciptakan

\footnotetext{
${ }^{1}$ Hasbullah, Dasar-dasar Ilmu Pendidikan, Jakarta: RajaGrafindo, 2012, hal. 4.

${ }^{2}$ Menurut Ki Hajar Dewantara, pertama kali yang harus kita ingat bahwa pendidikan merupakan suatu tuntunan di dalam hidup, tumbuhnya anak-anak itu terletak di luar kecakapan atau kehendak kita kaum pendidik. Anak-anak itu sebagai makhluk, sebagai manusia, teranglah hidup sesuai kodratnya sendiri...yang dikatakan kekuatan kodrat yang ada pada anak-anak itu tiada lain ialah segala kekuatan di dalam hidup batin dan hidup lahir dari anak-anak itu, yang ada karena kekuasaan kodrat. Pendidik hanya dapat menuntun tumbuhnya kekuatan tersebut agar dapat memperbaiki lakunya. Disarikan oleh Dedi Mulyasana, Pendidikan Bermutu dan Berdaya Saing, Bandung: Remaja Rosdakarya, 2012, hal. 5.

${ }^{3}$ Undang-undang Sistem Pendidikan Nasional Nomor 20 tahun 2003.

${ }^{4}$ Dedi Mulyasana, Pendidikan Bermutu dan Berdaya Saing ... hal. 5.
} 
tatanan kehidupan yang baik dan sejahtera diperlukan adanya sumber daya manusia yang unggul. Terciptanya sumber daya manusia unggul dapat teralisasi dengan adanya pola pendidikan yang baik yang dibangun bersama-sama antara pendidik, orang tua dan masyarakat dengan mengedepankan kemampuan intelektual, pembekalan keterampilan juga penanaman budi pekerti.

Jika diamati dari berbagai definisi pendidikan menurut berbagai tokoh pendidikan, penulis dapat mendefinisikan pendidikan sebagai usaha sadar dan terencana yang dilakukan oleh keluarga, sekolah, masyarakat dengan memberikan bimbingan, pengetahuan, keterampilan dan pembekalan budi pekerti yang bertujuan untuk menanamkan pengetahuan, keterampilan dan pembentukan watak kepribadian yang dapat menciptakan generasi yang dapat berdaya saing, cerdas intelektual dan soleh spiritual.

Selain menurut pandangan tokoh pendidikan, Islam menjelaskan pendidikan dengan berbagai istilah, salah satu istilah yang dapat mewakili dan memberikan rujukan mengenai konsep pendidikan adalah at-tarbiyyah. Kata at-tarbiyyah berasal dari kata $r a b b$ yang berarti membina/menumbuhkan sesuatu setahap demi setahap hingga mencapai batas yang sempurna. ${ }^{5}$

Kata at-tarbiyyah, yang berkaitan dengan pendidikan dapat ditemukan dalam Al-Qur’an surat Ali- Imran [3] 79 sebagai berikut:

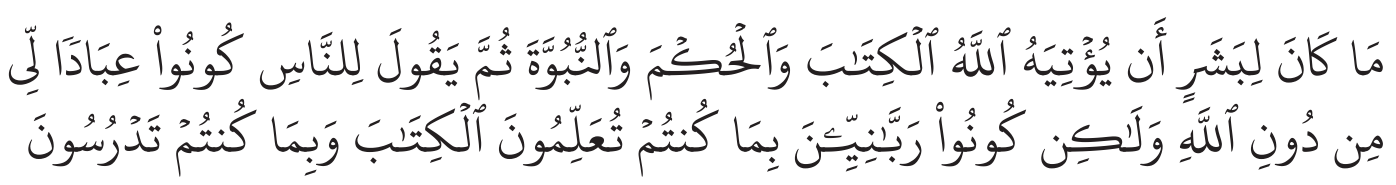

Tidak wajar bagi seseorang manusia yang Allah berikan kepadanya Al Kitab, hikmah dan kenabian, lalu dia berkata kepada manusia: "Hendaklah kamu menjadi penyembah-penyembahku bukan penyembah Allah". Akan tetapi (dia berkata): "Hendaklah kamu menjadi orang-orang rabbani, karena kamu selalu mengajarkan Al Kitab dan disebabkan kamu tetap mempelajarinya. (QS Ali Imran [3] 79).

Kata rabbânî mengandung pengertian orang yang sempurna ilmu dan takwanya kepada Allah SWT. Rabbânî adalah orang-orang yang memiliki ilmu pengetahuan yang sempurna yang terpanggil untuk mengajarkan ilmu dan ke-

\footnotetext{
${ }^{5}$ Menurut al-Raghib al-Asfahaniy “Tarbiyyah huwa insya al-syai halan fa halan ila had al-tamam .(Menumbuhkan/ membina sesuatu setahap demi setahap hingga mencapai batas yang sempurna). Disarikan oleh Abuddin Nata, Pendidikan dalam Perspektif Al-Qur'an, Jakarta: UIN Jakarta Press, 2005, hal. 90.
} 
mampuan wawasan pengetahuan untuk disebarkan kepada masyarakat, dalam makna sederhana kata rabbânî dapat diartikan sebagai pengajar atau pendidik. ${ }^{6}$

Dalam Islam, pendidikan merupakan hal yang fundamental, sehingga setiap muslim baik itu laki-laki maupun perempuan mempunyai kewajiban dan tanggung jawab yang sama untuk mencari ilmu dan mempunyai kesempatan yang sama untuk mendapatkan pendidikan. Rasyid Ridha berpendapat bahwa para ulama sepakat adanya kesamaan kewajiban menuntut ilmu bagi laki-laki dan perempuan. Seluruh masyarakat dengan struktur sosial, politik dan ekonomi yang berbedapun berkewajiban untuk menuntut ilmu dan membekali diri dengan ilmu serta mengkondisikan diri untuk melaksanakan kewajiban menuntut ilmu dengan sempurna. ${ }^{7}$ Karena itu tujuan pendidikan menurut Islam adalah tercermin dari tujuan hidup manusia yaitu beribadah kepada Allah SWT dan menjadi khalîfatullâh di bumi. ${ }^{8}$

Begitu pentingnya islam memberikan ruang kepada setiap manusia untuk mendapatkan pendidikan, karena dengan ilmu dan pendidikan yang baik, manusia dapat mengelola alam dan menciptakan teknologi yang tidak dapat diciptakan oleh makhluk lain dan dengan ilmu pengetahuan, manusia menjadi makhluk yang paling sempurna. Sejalan dengan tujuan hidup manusia, tujuan pendidikan menurut al-Ghazali adalah menjadi insan purna yang mendekatkan diri kepada Allah SWT dan menjadi insan purna yang bertujuan mendapatkan kebahagiaan di dunia dan akhirat. ${ }^{9}$ Isyarat tersebut sesuai dengan Al-Qur'an surat al-Baqarah [2] 201:

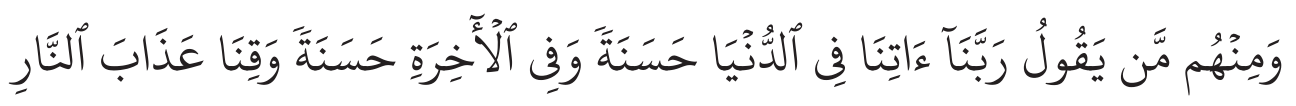

Dan di antara mereka ada orang yang berdoa: "Ya Tuhan kami, berilah kami kebaikan di dunia dan kebaikan di akhirat dan peliharalah kami dari siksa neraka (QS al-Baqarah [2] 201)."

Upaya yang dilakukan untuk memberikan pendidikan terhadap setiap manusia diharapkan dapat memberikan kebahagiaan dan ketenangan yang dapat dirasakan setiap manusia serta dapat memberikan nilai positif yang tertanam dalam diri manusia.

Sedangkan pengertian pendidikan anak adalah usaha yang dilakukan oleh keluarga, sekolah dan masyarakat untuk mendidik, membimbing dan me-

\footnotetext{
${ }^{6}$ Abuddin Nata, Pendidikan dalam Perspektif Al-Qur’an, ... hal. 92.

${ }^{7}$ Faqihuddin Abdul Kodir, Bergerak Menuju Keadilan, Jakarta: Rahima, 2006, hal. 26.

${ }^{8}$ Akhmad Alim, Tafsir Pendidikan Islam, Jakarta: AMP Press, 2014, hal. 42.

${ }^{9}$ Suwito, Sejarah Pemikiran Para Tokoh Pendidikan, Jakarta: Angkasa, 2003, hal. 160.
} 
ngarahkan anak-anak secara fitrah sehingga anak mampu berkembang dan hidup sesuai tahapan usia dan tahapan perkembangan anak-anak.

\section{B. Konsep Fitrah dalam Al-Qur'an}

Kata fitrah secara etimologi berasal dari berasal dari bahasa Arab yaitu fathara artinya belah atau pecah. ${ }^{10}$ Makna lain dari fitah adalah kejadian (al-ibtida) belahan (syiqaq), muncul (thulu), dan penciptaan (khalqun). ${ }^{11}$ Dari berbagai makna yang terkandung tersebut masing-masing makna saling melengkapi dimana makna syiqah berarti belahan dan dalam Al-Qur'an disebutkan untuk objek langit sedangkan jika diteliti dan diumpamakan kepada manusia makna tersebut dapat menjelaskan tentang proses penciptan manusia juga melalui tahapan pembelahan (syiqaq). Sedangkan fitrah bermakna kejadian (al-ibtida) adalah proses penciptaan yang terdiri dari penciptaan langit bumi dan penciptaan manusia.

Menurut terminologi, fitrah didefinisikan sebagaimana menurut alRaghib al- Isfahani adalah mewujudkan dan mengadakan sesuatu sesuai kondisi yang dipersiapkan untuk melakukan perbuatan tertentu. Dari pengertian ini dapat difahami bahwa Allah telah menciptakan manusia dengan potensi yang dimiliki untuk melakukan perbuatan dalam kehidupannya. ${ }^{12}$ Pendapat al-Isfahani juga sebagaimana pengertian fitrah menurut Muhamad Arifin yang menjelaskan fitrah sebagai potensi dasar manusia yang hadir sejak lahir dan mengandung komponen psikologi yang saling berkaitan. Lebih jelas Arifin menjelaskan bahwa komponen manusia tersebut meliputi kemampuan dasar beragama, kemampuan dasar terhadap keingintahuan tentang kebenaran dan kemampuan dasar berupa daya dan kekuatan yang memungkinkan manusia menjadi manusia paripurna. Sedangkan Ahmad Warsono Munawar mendefinisikan fitrah sebagai sifat pembawaan sejak lahir. ${ }^{13}$ Jika dihubungkan dengan manusia fitrah mengandung arti bahwa Allah SWT menciptakan manusia dengan potensi tabiat, perangai, kejadian asal, penciptaan dan agama yang semuanya dimiliki semenjak lahir.

${ }^{10}$ Mahmud Yunus. Kamus Arab Indonesia, Jakarta: Yayasan Penyelenggaraan Penterjemahan dan Tafsir Al-Qur'an, 1973, hal. 319.

${ }^{11}$ Al- munjid fi Lugghat, Libanon: Dar el-Masyrik, 1997, hal. 588.

${ }^{12}$ Al-Raghib al-Asfahaniy, Mu’jam Mufradat al-Fadl Al-Qur’an, Beirut: Dar el-Fikr, 1972, hal. 396.

${ }^{13}$ Ahmad Warsono Munawar, Kamus Arab Indonesia al-Munawir, Surabaya: Pustaka Progresif, 1997, cet-14, hal. 1062. 


\section{Pendidikan Anak Berbasis Fitrah Perspektif Al-Qur'an}

Al-Qur'an secara detail menjelaskan mengenai proses dan eksistensi manusia sebagai makhluk hidup yang mempunyai potensi dan kecerdasan dibanding makhluk lainnya. Gambaran mengenai eksistensi manusia tersebut Allah isyaratkan dalam Al-Qur'an surat an-Nahl [16] 78 sebagai berikut:

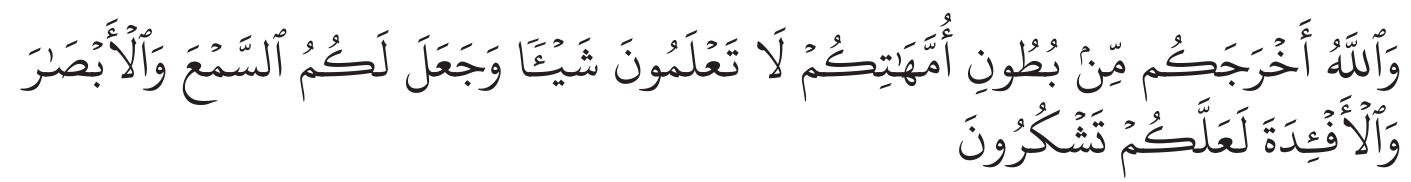

Dan Allah mengeluarkan kamu dari perut ibumu dalam keadaan tidak mengetahui sesuatupun, dan Dia memberi kamu pendengaran, penglihatan dan hati, agar kamu bersyukur. (QS al-Nahl [16] 78).

Kandungan Al-Quran di atas menjelaskan bahwa Allah menciptakan manusia melalui rahim ibu kemudian Allah berikan pendengaran, penglihatan dan hati. Menarik jika ditelaah mengenai urutan yang Allah ciptakan. Pertama Allah ciptakan pendengaran (telinga), penglihatan (mata) dan hati. Urutan tersebut dalam tafsir al-Sya'rawi menjelaskan bahwa urutan tersebut alamiah. ${ }^{14} \mathrm{Da}$ lam kehidupan nyata seorang bayi lahir maka telinga sebagai alat pendengaran yang pertama berfungsi, meskipun pada tahap selanjutnya mata memiliki ketajaman dalam menerima respon dibanding telinga.

Sedangkan menurut Abu Muhammad Makki al-Qairuwani yang disarikan Darwis Hude menjelaskan bahwa Allah SWT mengajari manusia dalam rahim ibu sesuatu yang belum diketahuinya, kemudian Allah SWT membekali manusia dengan kemampuan pendengaran, penglihatan dan hati yang berfungsi untuk membedakan antara yang baik dan benar, memahami sesuatu serta mendengarkan perintah dan ajaran Allah SWT. ${ }^{15}$

Tidak hanya telinga dan mata yang memiliki manfaat untuk kehidupan manusia. Dolman menjelaskan bahwa hati juga memiliki peranan penentu, ketika telinga dan mata menerima rangsang suara dan visual, pesan pendengaran dan penglihatan diuraikan menjadi serentetan impuls-impuls elektrokimia dan diteruskan ke otak untuk disusun dan diartikan menjadi kata-kata yang dapat dipahami. operating system otak dalam memahami susunan impuls elektrokimia adalah hati. Jika otak diumpamakan hardware maka hati adalah software. ${ }^{16}$

\footnotetext{
${ }^{14}$ Muhammad Mutawalli Asy-Sya'rawi, Tafsir As-Sya'rawi, hal. 1963.

${ }^{15}$ Darwis Hude, Logika Al-Qur’an, Jakarta: Eurobia, 2015, hal. 51-52.

${ }^{16}$ Dedhi Suharto, Qur'anic Intelligence Quotient, Tangerang: FBA Press2006, cet 2, hal. 27-28.
} 
Selain memberikan kemampuan pendengaran, penglihatan dan hati, Allah SWT memberikan potensi agama atau disebut fitrah. Dalam pandangan Islam, Allah SWT menganugerahkan potensi yang terdapat dari diri manusia yang memiliki unsur jasmaniah (fisiologis) dan unsur ruhaniah (psikologis) dengan berbagai potensi sebagai bekal kehidupan manusia. Dalam unsur yang terkandung tersebut Allah memberikan seperangkat kemampuan dasar yang memiliki kecenderungan berkembang (disposisi/potensialitas) atau dalam aliran psikologi behaviorisme disebut dengan kemampuan dasar yang otomatis berkembang (prepotence reflexes). ${ }^{17}$

Berikut ini akan dijelaskan mengenai fitrah yang telah Allah SWT berikan kepada manusia.

\section{Fitrah Keimanan}

Kata fitrah secara etimologi berasal dari Bahasa Arab "Fathara" yang berarti pecah atau belah. ${ }^{18}$ Sedangkan menurut istilah fitrah sebagaimana didefinisikan Muhamad Arifin yaitu kemampuan dasar atau potensi dasar manusia yang dibawa sejak lahir. ${ }^{19}$ Al-Jurjani mendefinisikan fitrah sebagai potensi yang siap menerima agama. ${ }^{20}$ Pendapat al-Jarnuji tersebut sebagaimana tertuang dalam Al-Qur'an surat al-Ruum [30] 30:

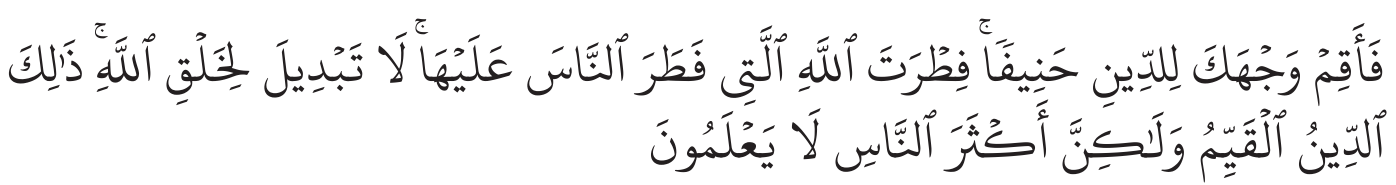

Maka hadapkanlah wajahmu dengan lurus kepada agama Allah; (tetaplah atas) fitrah Allah yang telah menciptakan manusia menurut fitrah itu. Tidak ada perubahan pada fitrah Allah. (Itulah) agama yang lurus; tetapi kebanyakan manusia tidak mengetahui.

Penjelasan mengenai fitrah manusia ini juga terdapat dalam hadits riwayat Bukhari: ${ }^{21}$

\footnotetext{
${ }^{17}$ Arifin, Ilmu Pendidikan Islam: Tinjauan Teoritis dan Praktis Berdasarkan Pendekatan Interdisipliner, Jakarta: Bumi Aksara, 2003, hal. 42.

${ }^{18}$ Mahmud Yunus, Kamus Arab-Indonesia, Jakarta: Yayasan Penyelenggaraan Penterjemahan Tafsir Al-Qur’an, 1973, hal. 319.

${ }^{19}$ Fitrah merupakan potensi dasar manusia yang engandung komponen psikologis yang saling terkait meliputi kemampuan dasar untuk beribadah, emampuan dasar berupa rasa ingin tahu terhadap kebenaran, kmampuan dasar yang memungkinkan manusia untuk menjadi mulia. $\mathrm{Mu}$ hammad Arifin, Ilmu Pendidikan Islam, Jakarta: Bumi Aksara, 1996, hal. 82

${ }^{20}$ Ali ibnu Muhammad al-Jurjani, At-Ta’rifat, juz 1, hal. 53.

${ }^{21}$ Muhammad ibn Isma'il Al-Bukhari, Shahih Bukhari, juz 5, hadis nomor 1296, hal. 182.
} 


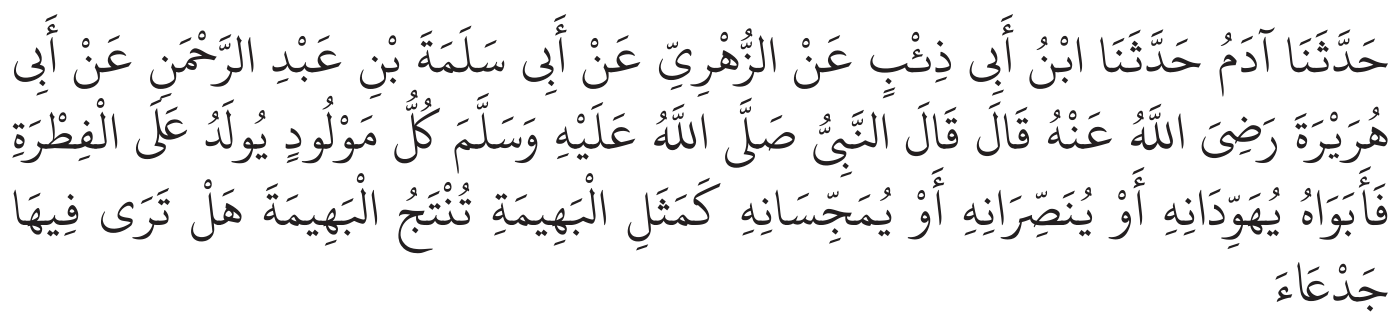

Telah menceritakan kepada kami Adam telah menceritakan kepada kami Ibnu Abu Dza'bi dari Az Zuhriy dari Abu Salamah bin 'Abdurrahman dari Abu Hurairah radliallahu 'anhu berkata; Nabi Shallallahu'alaihiwasallam bersabda: "Setiap anak dilahirkan dalam keadaan fitrah. Kemudian kedua orang tuanyalah yang akan menjadikan anak itu menjadi Yahudi, Nashrani atau Majusi sebagaimana binatang ternak yang melahirkan binatang ternak dengan sempurna. Apakah kalian melihat ada cacat padanya?"

Dalam kandungan ayat Al-Qur'an surat al-Rûm/30: 30 dan hadits yang diriwayatkan Bukhori tersebut, mengandung pengertian, pertama fitrah dalam ayat tersebut mengandung makna potensi dasar beragama yang benar dan lurus dan ini ketetapan dari Allah, maka dalam ayat tersebut mengandung implikasi yang berkonotasi dengan aliran pendidikan nativisme. Kedua dalam hadits tersebut terdapat faktor bawaan yang dipengaruhi potensi atau faktor luar, ${ }^{22}$ karena setiap individu juga sudah dibekali dengan pendengaran, penglihatan dan hati. Dari uraian tersebut dijelaskan bahwa setiap manusia mempunyai potensi sejak dalam kandungan, potensi itu bernama tauhid, kemudian akan ber kembang dan bertambah seiring dengan lingkungan dan pola pendidikan yang diterima oleh setiap orang. Untuk itu orang tua (keluarga), sekolah dan m asyarakat menjadi lembaga yang sangat berpengaruh terhadap perkembangan dan perubahan setiap potensi.

Potensi (fitrah) yang dijelaskan Al-Qur'an berbeda dengan teori Jhon Luck yaitu teori Tabularasa. Dalam teori tersebut setiap anak yang terlahir bagaikan kertas kosong, lingkungan yang akan mengisi potensi tersebut. Sedangkan Al-Qur'an menjelaskan bahwa setiap anak yang terlahir telah membawa potensi (fitrah), kemudian lingkungan keluarga, sekolah dan masyarakat yang melengkapi dan membentuk lebih lanjut potensi tersebut.

Menurut Mohammed pemahaman mengenai fitrah manusia dan bagaimana kemampuannya untuk berkembang dapat dikelompokkan menjadi em-

${ }^{22}$ Arifin, Ilmu Pendidikan Islam: Tinjauan Teoritis dan Praktis Berdasarkan Pendekatan Interdisipliner, ... hal. 44-45 
pat. ${ }^{23}$ Pertama, fatali s-pasif pelopornya adalah Ibn Mubarok, Abdul Qadir Jailani, dan al-Azhari menjelaskan bahwa setiap individu melalui ketetapan Allah adalah baik atau buruk secara asal, baik ketetapan ini terjadi sebagian atau keseluruhan. Kedua netral-pasif tokoh aliran ini adalah ibnu Abd al-Baar menjelaskan bahwa setiap individu lahir dalam keadaan suci, utuh dan sempurna suatu keadaan kosong sebagaimana adanya, tanpa kesadaran akan iman atau kufur atau jahat. Teori ini sama dengan teori tabularasa. Ketiga, Positif-aktif, tokoh aliran ini adalah Ibnu Taimiyah, Ibnu Qayyim al-Jauziyah, aliran ini menjelaskan bahwa bawaan setiap individu adalah baik adapun kejahatan adalah aksidental. Keempat Dualis aktif tokoh aliran ini adalah Sayyid Qutb al-Jamaly dan 'Ali Shariati aliran ini menjelaskanbahwa potensi setiap individu disatu sisi cenderung kepada kejahatan dan cenderung kepada kebaikan. sifat dualis ini sama-sama aktif dalam keadaan setara.

Sedangkan menurut Abdurrahman Saleh Abdullah, ${ }^{24}$ hakikat makna fitrah bersumber dari salah satu ayat Al-Qur'an surat al-A'raf [7] 172:

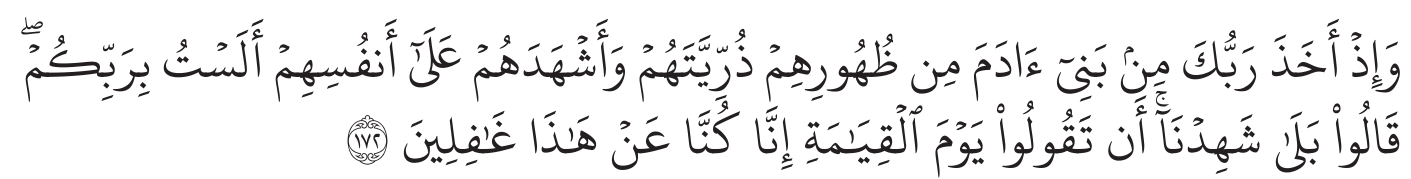

Dan (ingatlah), ketika Tuhanmu mengeluarkan keturunan anak-anak Adam dari sulbi mereka dan Allah mengambil kesaksian terhadap jiwa mereka (seraya berfirman): "Bukankah Aku ini Tuhanmu?" Mereka menjawab: "Betul (Engkau Tuhan kami), kami menjadi saksi”. (Kami lakukan yang demikian itu) agar di hari kiamat kamu tidak mengatakan: "Sesungguhnya kami (bani Adam) adalah orang-orang yang lengah terhadap ini (keesaan Tuhan)" (QS al'A'raf [7] 172)

Ibnu Katsir menjelaskan bahwa ayat ini adanya kesadaran dan kesaksian manusia dalam bentuk perjanjian saat bertemunya ruh dengan jasad. Saat itu terjadi perjanjian antara manusia dan Allah dengan menjadikan Allah sebagai Tuhan manusia. ${ }^{25}$ Ayat di atas juga menjelaskan tentang tauhid sebagai landasan pokok dimana Allah membuat perjanjian kepada manusia ketika dalam rahim

${ }^{23}$ Abdur Rahman Assegaf, Pendidikan Islam di Indonesia, ... hal. 61-64.

${ }^{24}$ Razi sebagaimana yang disarikan oleh Abdurrahman Saleh Abdullah menjelaskan bahwa Ayat tersebut menjelaskan bahwa keturunan (anak-anak) dalam ayat tersebut berasal dari orang tua mereka. Sebagaian penafsiran menjelaskan bahwa perjanjian dalam ayat tersebut adalah antara Allah dan manusia yang diberikan setelah keturunannya. Maka untuk itu fitrah diartikan dengan Islam. Abdurrahman Saleh Abdullah, Teori-teori Pendidikan Berdasarkan Al-Qur'an, Jakarta: Rineka Cipta, 1990, hal. 56-57. juz 3, hal. 500

${ }^{25}$ Ibnu Katsir, Tafsir Al-Qur’an al-'Azim, Beirut: Dar Tayyibahli al-Nasyr wa al-Tawzi, 1999, 
ibu dengan berkata “Bukankah Aku ini Tuhanmu?' Mereka menjawab: “Betul (Engkau Tuhan kami), kami bersaksi." Petikan ayat tersebut menjelaskan bahwa setiap manusia dalam kandungan ibu sudah meyakinkan diri bahwa Allah SWT sebagai Tuhan manusia. ini menunjukkan fitrah manusia mulai dari kandungan sudah membawa fitrah tauhid. Untuk itu Allah memberi potensi manusia baik dan buruk, potensi itu diberikan karena manusia dibekali dengan akal sehingga dapat memilih mana yang baik dan perbuatan mana yang buruk. Dengan akal manusia memiliki kemampuan membuat keputusan (decision making), memecahkan masalah (problem solving), atau menghubungkan berbagai pengetahuan menjadi pengetahuan yang baru (creativity). ${ }^{26}$

Fitrah keimanan ini akan tumbuh pada usia 0-7 tahun, karena pada usia ini anak berada dalam imajinasi dan abstraksi puncak, bawah alam sadarnya terbuka luas, sehingga kesan-kesan tentang Allah, rasul, tentang kebajikan, dan tentang alam raya ini mudah untuk diingatkan dan dibangkitkan. ${ }^{27}$ Cara yang efektif untuk menumbuhkan fitrah ini adalah dengan memberikan tauladan dan pemahaman juga kesan positif akan Allah swt, Rasulullah dana lam raya ini dengan metode berdongeng dan melihat kebesaran Allah swt, sehingga lambat laun pemahaman anak-anak tentang keimanan akan kuat.

\section{Fitrah Belajar}

Salah satu potensi manusia adalah makhluk pembelajar. Kecenderungan manusia untuk selalu belajar terlihat jelas ketika masa bayi dan kanak-kanak. Proses perkembangan dari mulai lahir sampai kanak-kanak dilalui dengan selalu belajar dan mencoba, mulai dari telungkup terus merangkak, duduk dan akhirnya berjalan dilakukan dengan antusias dan rasa ingin tahu yang kuat. Selain perkembangan fisik, kemampuan kognitif dan daya nalar mulai berkembang, hal ini ditandai dengan dijadikannya berbagai sudut dan tempat sebagai bahan eksperimen dengan rasa ingin tahu yang tinggi tidak perlu tempat, waktu dan guru secara khusus anak-anak dapat berimajinasi dan melakukan eksperimen secara alami, ini yang disebut dengan fitrah belajar.

Dalam psikologi perkembangan anak, usia anak sebagai pembelajar dapat terlihat jelas saat usia 7-12 tahun, pada usia ini pertumbuhan otak kanan dan otak kiri tumbuh seimbang, sifat individual dan ego sentris mulai bergeser ke sikap sosial sentris sehingga mulai terbuka pada dunia luar dan indera sensomotoris sudah tumbuh sempurna, maka dalam ajaran Islam, anak pada usia

${ }^{26}$ Darwis Hude, Logika Al-Qur'an ..., hal. 31.

${ }^{27}$ Harry Santosa, Fitrah Based Education: Sebuah Model Pendidikan Peradaban bagi Generasi Peradaban menuju Peran Peradaban, Depok: Yayasan Cahaya Mutiara Timur, 2017, cet-3, hal. 159. 
7 tahun diperintahkan untuk sholat karena pada usia ini nilai-nilai keimanan suduh tumbuh dengan adanya potensi keimanan pada usi sebelumnya yaitu usia 0-7 tahun berganti pada semangat untuk belajar. ${ }^{28}$

Isyarat mengenai fitrah belajar telah Allah swt contohkan melalui Nabi Adam as, yang ketika tinggal di bumi diajarkan bermacam-macam nama-nama yang ada di bumi, sebagaimana Allah jelaskan dalam surat al-Baqarah [2] 31-32:

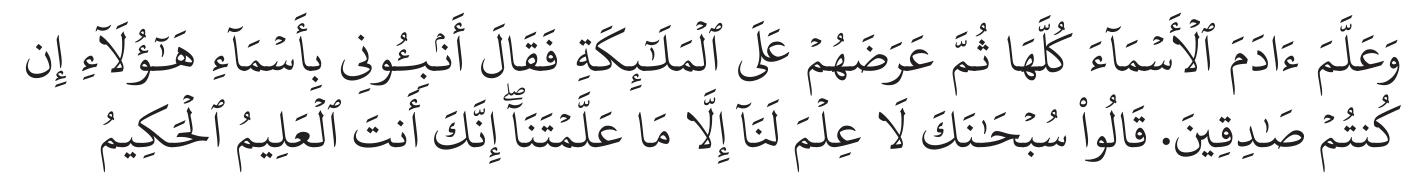

Dan Dia mengajarkan kepada Adam nama-nama (benda-benda) seluruhnya, kemudian mengemukakannya kepada para Malaikat lalu berfirman: "Sebutkanlah kepada-Ku nama benda-benda itu jika kamu mamang benar orang-orang yang benar!

Mereka menjawab: "Maha Suci Engkau, tidak ada yang kami ketahui selain dari apa yang telah Engkau ajarkan kepada kami; sesungguhnya Engkaulah Yang Maha Mengetahui lagi Maha Bijaksana" (QS al-Baqarah [2] 31-32).

Kandungan ayat di atas menjelaskan bahwa, manusia merupakan makhluk yang dipersiapkan Allah SWT menjadi makhluk berpengetahuan yaitu dengan diajarkannya Nabi Adam tentang bermacam-macam nama. Kata 'allama dalam bahasa Arab mengandung makna yang menujukkan waktunya lama bahkan berlangsung seumur hidup. ${ }^{29}$ Selain ayat di atas potensi manusia sebagai makhluk pembelajar dengan diberikan potensi kecerdasan terdapat dalam AlQur’an sebagaimana yang diwahyukan Allah SWT dalam Al-Qur'an surat al-Isra [17] 70:

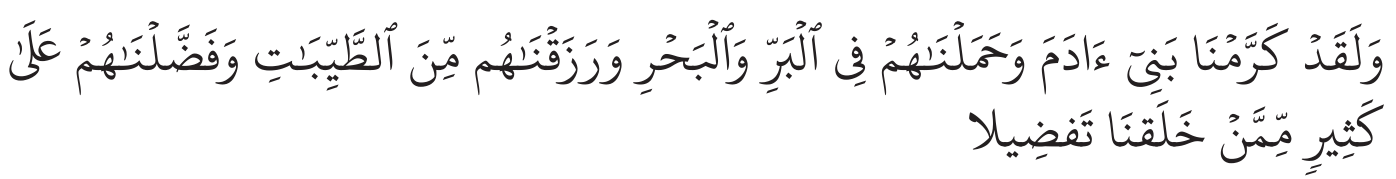

${ }^{28}$ Pada tahap ini adalah golden age pada fitrah belajar, anak-anak mulai kritis. Hendaknya orang tua menguatkan anak-anak tentang keimanan melalui beragam aktifitas produktif di alam raya dan lingkungan yang lebih luas. Karena pada usia ini semua tempat dan seluruh waktu dapat dijadikan pembelajaran yaitu dengan melakukan eksperimen, selain itu pada usia ini terus diberikan pendidikan karakter dengan mencontohkan sikap mulia. Harry Santosa, Fitrah Based Education: Sebuah Model Pendidikan Peradaban bagi Generasi Peradaban menuju Peran Peradaban, ... hal.292.

${ }^{29}$ Menurut Ibn Abbas dalam Tafsir ibn Katsir menjelaskan bahwa nama-nama manusia dan binatang. Sedangkan menurut Ibn Jarir ath-Thabari dalam Tafsir ath-THabari menjelaskan bahwa memaknai al-asma' dengan al di depannya mengandung nama istighraq yaitu meliputi seluruh genius nama. Nanang Gojali, Tafsir dan Hadits tentang Pendidikan, ... hal. 58. 
Dan sesungguhnya telah Kami muliakan anak-anak Adam, Kami angkat mereka di daratan dan di lautan, Kami beri mereka rezeki dari yang baikbaik dan Kami lebihkan mereka dengan kelebihan yang sempurna atas kebanyakan makhluk yang telah Kami ciptakan (QS al-Isra' [17] 70).

Menurut al-Khazin, Allah memuliakan manusia dari semua makhluk yang ada di alam raya ini yang bersifat fundamental secara alamiah, seperti potensi akal pikiran, verbal, grafis, dan bentuk yang serba seimbang, dengan penganugerahan potensi tersebut manusia mampu mengubah dan mengembangkan budaya secara progresif sejalan dengan kebutuhan dan dinamika kehidupan dan lingkungan manusia. ${ }^{30}$

Al-Zamakhsyari, seorang ahli tafsir klasik, berpendapat bahwa kemuliaan yang diberikan Allah kepada manusia dalam ayat di atas adalah penganugerahan akal yang digunakan untuk berfikir, berkreasi, sekaligus membedakan antara baik dan buruk. Kemuliaan tersebut menjadi modal bagi manusia untuk mengelola dan menundukkan potensi bumi. Kekuatan akal inilah yang membedakan antara manusia dengan makhluk lainnya. ${ }^{31}$

Untuk memunculkan fitrah belajar pada anak-anak, hendaklah orang tua memiliki kedekatan baik secara fisik maupun psikis ketika anak-anak belajar bersama orang tua selain itu akrabkan anak-anak dengan alam semesta dengan melakukan pembelajaran di alam dalam bentuk percobaan sederhana untuk meyakinkan pengetahuan yang anak-anak terima, serta berikan pemahaman kepada anak-anak bahwa apa yang ada di alam raya ini adalah kuasa dari Allah swt, sehingga dengan cara ini kemampuan nalar dan belajar anak-anak akan bebanding lurus dengan keimanan.

Ada beberapa hal yang seharusnya dilakukan oleh orang tua maupun pengajar pada usia 7-12 tahun yaitu, Pertama, menumbuhkan percaya diri dengan memberikan kekeluasaan anak-anak untuk melakukan pembelajaran agar daya kreatifitasnya akan selalu hadir. Kedua, memberikan materi belajar dengan diimbangi latihan-latihan dan praktek-praktek di alam bebas atau menggunakan bahan-bahan sederhana, sehingga memungkinkan anak merasa terus bersemangat karena mampu menciptakan berbagai ide dalam setiap kesempatan belajar. Ketiga, buku-buku atau materi yang diajarkan hendaklah dapat menggugah semangat belajar juga bernilai tauladan dalam kehidupan sehari-hari sehingga anak mampu berimajinasi dan berfikir praktis dalam melakukan so50.

${ }^{30}$ Al-Khazin, disarikan oleh Darwis Hude, Logika Al-Qur’an, Jakarta: Eurobia, 2015, hal.

${ }^{31}$ Al-Imam Abu al-Qasim Jarullah Mahmud bin 'Umar al-Zamakhsyari, al-Kasysyaf 'an Haqaiq al-Tanzil wa al-‘Uyun al-Aqawil fi wujuh al-Ta’wil, Beirut: Dar al-Kitab al-'Arabi, tth, Jilid 2, hal. 653. 
sialisasi dengan teman-teman dan lingkungannya disertai dengan pembiasaan karakter yang baik. Keempat, meminimalisir kegiatan yang bersifat kompetisi karena akan menimbulkan rasa takut dan tidak percaya diri karena ketika anakanak kalah maka akan merasa lemah sehingga rasa ingin tahunya akan sirna.

\section{Fitrah Bakat}

Bakat adalah potensi bawaan lahir yang dimiliki manusia. ${ }^{32}$ Karena berasal dari bawaan lahir, maka bakat merupakan fitrah. Setiap anak membawa fitrah bakat masing-masing, karena fitrah maka bakat bukan hasil dari bentukan. Keunikan bakat anak-anak dapat didentifikasi dari aktifitas keseharian, jika anak senang melakukan satu aktifitas dan dilakukan berulang-ulang bisa jadi merupakan bakat. Namun orang tua juga harus dapat membedakan mana bakat dan minat. Jika bakat merupakan bawaan lahir dan alamiah maka minat (passion) adalah keiginan hati terhadap sesuatu dan biasanya ketika anak-anak melakukan itu dengan rasa senang. Sebagai contoh ketika anak-anak senang bernyanyi, maka biasanya diiringi dengan suara yang bagus. Bernyanyi adalah bakat sedang keinginan untuk bernyanyi adalah minat.

Potensi bakat setiap anak dapat dilihat ketika anak berusia 10-14 tahun, karena pada usia ini anak masuk pada tahap pre-aqilbaligh, dimana anak-anak secara fitrah sudah tertanam fitrah keimanan, dan fitrah belajar dan berfikir logis, sehingga memungkinkan dari keyakinan yang didapatkan dan pembelajaran juga eksperimen yang dilakukan dapat memperkuat potensi bakat yang telah ada sejak lahir. Isyarat mengenai potensi bakat tertuang dalam Al-Qur'an Surat al-Isra [17] 84:

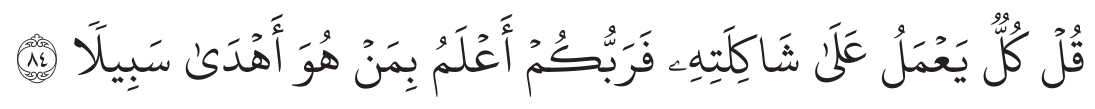

Katakanlah: "Tiap-tiap orang berbuat menurut keadaannya masing-masing”. Maka Tuhanmu lebih mengetahui siapa yang lebih benar jalannya (QS al-Isra [17] 84).

Kandungan ayat di atas sebagaimana dijelaskan oleh ibnu Qayyim bahwa jika orang tua melihat dan mengamati anaknya bagus pemahamannya, dapat mengerti dengan baik, cerdas dan memiliki hafalan, maka ini menunjukkan kesiapannya untuk jadi pembelajar (belajar) dan menerima ilmu baik dari orang tua maupun pendidik. Namun apabila orang tua meliaht anaknya memiliki potensi pada perdagangan, jual beli atau bidang lain yang diperbolehkan oleh syariat

${ }^{32}$ Ayah Edy, Rahasia Ayah Edy Memetakan Potensi Unggul Anak, Jakarta: Noura Books, 2015, cet-9, hal. xii. 
(seperti bidang kedokteran, pertanian, teknologi dan lain-lain) maka hendaklah orang tua untuk memberikan kesempatan kepada anak-anaknya mengembangkan potensi tersebut, karena setiap orang menurut ayat di atas akan diberikan oleh Allah swt kemudahan melakukan apa yang ditetapkan oleh Allah. ${ }^{33}$

Jika membaca dengan seksama penjelasan ibnu Qayyim tersebut ini mengisyaratkan bahwa peran orang tua sangat mendukung terbentuknya potensi bakat pada anak. Untuk itu perlu kiranya orang tua menstimulus potensi tersebut dengan cara mengapresiasi setiap aktifitas yang disukai anak, menghargai anak dengan memberikan sebutan positif kepada anak, memberikan kebebasan berekspresi dalam setiap kegiatan kepada anak selama tidak membahayakan dan melanggar ketentuan syar'i, Memberikan reward dan punishment yang mendidik kepada anak, dan tidak membebani dan menekan anakuntuk selalu berprestasi di sekolah. ${ }^{34}$

Untuk itu kiranya setiap orang tua mengetahui ciri-ciri potensi bakat pada anak. Munif Chatib ${ }^{35}$ menjelaskannya, pertama, aktifitas yang disukai anak tidak dapat dibatasi, jika anak menyukai suatu aktifitas yang berhubungan dengan bakat maka semua ruang akan dijadikan tempat untuk aktifitasnya, jika dilarang maka akan mencari celah untuk terus melakukan aktifitas tersebut. Kedua, memunculkan momen spesial (special moment), dimana dengan bakat yang dimilikinya anak mampu memunculkan hal-hal yang luar biasa tanpa dapat diduga sebelumnya, maka orang tua harus terus berupaya menyadari akan situasi dan momen yang memunculkan fitrah bakat tersebut. Ketiga, merasa nyaman dan semangat mempelajari aktifitas yang disukai, hal ini dapat terlihat dari ekspresi dan raut wajah senang dan bersemangat ketika melakukan aktifitas tersebut, meskipun bagi sebagian anak aktifitas tersebut susah dan menantang. Keempat, anak akan menjadi pembelajar yang cepat (fast learner) karena aktifitas dan proses belajar yang dilalui menyenangkan sehingga anak merasa mudah

\footnotetext{
${ }^{33}$ Orang tua harus memperhatikan keadaan anak, potensi yang dimiliki, bakat yang yang terpendam dan mengapresiasi bakat yang dimiliki, dan orang tua hendaknya mengetahui bidang itulah anak-anaknya diiptakan. Dan orang tua seharusnya tidak memalingkan anak-anak terhadap bakatnya selama sesuai tuntunan syariat, akan tetapi jika anak dipaksa untuk focus pada hal yang bukan potensi bakatnya, maka anak tersebut tidak akan meraih kesuksesan dan hilanglah apa yang menjadi potensinya. Disarikan oleh Harry Santosa, Fitrah Based Education: Sebuah Model Pendidikan Peradaban bagi Generasi Peradaban menuju Peran Peradaban, ... hal. 176.

${ }^{34}$ Potensi bakat pada anak jika diumpamakan seperti tunas-tunas kecil yang tumbuh, jika dirawat dengan baik dan diberikan stimulus baik berupa makanan, vitamin atau tauladan yang baik maka akan tumbuh menjadi tunas yang tumbuh dan bersemi, namun jika orang tua membiarkan dan menekan tunas-tunas yang tumbuh maka secara tidak langsung orang tua menjadi mesin pembunuh bakat anak-anak. Munif Chatib, Orang Tuanya Manusia: Melejitkan Potensi dan Kecerdasan dengan Menghargai Fitrah Setiap Anak, Bandung: Kaifa, 2015, hal. 131-133.

${ }^{35}$ Munif Chatib, Orang Tuanya Manusia: Melejitkan Potensi dan Kecerdasan dengan Menghargai Fitrah Setiap Anak, Bandung: Kaifa, 2015, hal. 134-138.
} 
untuk melakukan, jika ada masalah dalam aktifitasnya anak yang berbakat akan mencari solusi dari aktifitas yang dilakukan. Kelima, selain menimbulkan kesenangan dan kebahagiaan, potensi bakat juga dapat menghasilkan karya dan bernilai ekonomi dan anak akan berasi untuk menampilkan dan melakukan pertunjukan dari hasil aktifitasnya. Dengan mengetahui ciri-ciri bakat pada anak-anak, orang tua akan lebih mudah mengarahkan dan memfokuskan aktifitas untuk dapat lebih cepat menemukan potensi bakat anak-anak, sehingga proses pendidikan dan pembelajaran baik yang dilakukan orang tua maupun pengajar dapat dengan mudah dilaksanakan oleh anak.

\section{Fitrah Alam}

Fitrah alam adalah semua potensi unik yang diberikan oleh Allah swt kepada alam raya ini (bumi) dimana seseorang ditakdirkan lahir dan mendiami ruang tersebut. ${ }^{36}$ Sebagai khalifah di bumi ini manusia memiliki peran yang sangat menentukan, karena semua kekayaan hayati dan hewani yang ada di bumi ini dapat dimanfaatkan untuk kepentingan manusia. Untuk itu perlunya memberikan pemahaman kepada anak-anak bahwa bumi dan segala isinya merupakan fasilitas yang Allah swt berikan untuk dimanfaatkan sebaik-baiknya. Selain itu anak-anak juga harus diberikan pengertian akan kecintaan terhadap wilayah yang dipijaknya, karena dimanapun manusia lahir dan hidup bukanlah suatu kebetulan, karena Allah swt telah menakdirkan manusia untuk lahir di wilayah tersebut dengan dibekali berbagai potensi dan kekuatan fisik dan psikis untuk dapat bertahan di wilayah tersebut. Selain itu fitrah ala mini akan berkaitan dengan hubungan social yang ada di sekitarnya. Ikatan social akan kuat jika setiap manusia menyadari akan tujuan diciptakan disuatu suku, bangsa, dengan berbeda bahasa, adat istiadat, budaya dan potensi daerah masing-masing. Tujuan kehidupan sosial dana lam tersebut telah diisyaratkan dalam al-Quran Surat al-Hujurat [49]13:

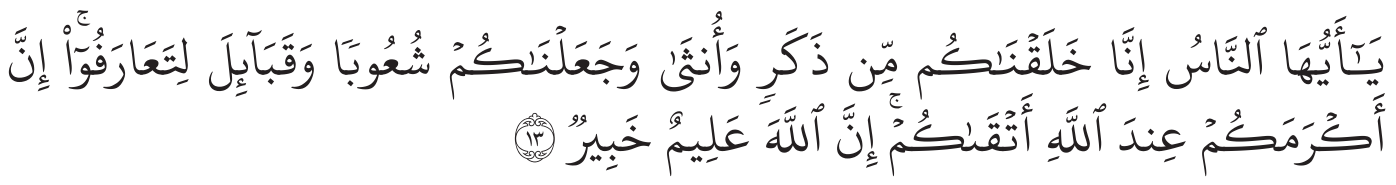

Hai manusia, sesungguhnya Kami menciptakan kamu dari seorang laki-laki dan seorang perempuan dan menjadikan kamu berbangsa-bangsa dan bersuku-suku supaya kamu saling kenal-mengenal. Sesungguhnya orang yang paling mulia diantara kamu disisi Allah ialah orang yang pa-

${ }^{36}$ Harry Santosa, Fitrah Based Education: Sebuah Model Pendidikan Peradaban bagi Generasi Peradaban menuju Peran Peradaban, ... hal. 208. 
ling takwa diantara kamu. Sesungguhnya Allah Maha Mengetahui lagi

Maha Mengenal. (QS al-Hujurat [49]13).

Isyarat Al-Qur'an tentang tujuan manusia yang diciptakan antara laki-laki dan perempuan dan menjadikan bersuku-suku, berbangsa-bangsa dan beragam bahasa adalah untuk saling mengenal. Keunikan dari isyarat tersebut untuk manusia adalah mengajarkan kepada anak-anak bahwa bumi Allah swt itu terbentang luas, kekayaan yang diberikan Allah swt itu untuk kehidupan manusia, untuk itu orang tua harus mengetahui potensi yang ada di wilayah tersebut untuk diberikan pengetahuan anak sebagai pengetahuan lokal yang dapat menumbuhkan fitrah alam.

Selain itu dengan memberikan pemahaman dan pengertian mengenai potensi alam yang ada di sekitarnya, memungkinkan anak akan tumbuh dan besar mengikuti kehidupan sosial yang ada di wilayahnya serta tertanam potensi alam. Sebagai contoh seorang anak yang hidup di wilayah kelautan, maka tugas orang tua adalah mendidik anak-anak untuk tetap hidup dan bertahan bahkan membangun wilyahnya dengan memberikan pemahaman tentang lingkungan kelautan, sehingga ketika nalar kritisnya sudah hadir maka anak akan memilih melestarikan wilayahnya dan membangun wilayahnya dengan potensi kelautan yang dimiliki. Hidup di daerah laut bukan berarti anak-anak diarahkan hanya menjadi nelayan, akan tetapi terdapat sumber potensi alam yang dapat di miliki anak-anak seperti kemampuan budidaya perikanan, kemampuan untuk navigasi perbintangan, belajar mengenai pengelolaan bencana laut, belajar mengenai pembuatan kapal laut. Selain itu potensi yang dikembangkan selanjutnya anakanak dibekali dengan pengetahuan manajemen usaha, kepemimpinan, peneliti, pemasaran membuat strategi dagang dan straegi memakmurkan nelayan, Dengan memembuka ruang potensi alam yang ada, anak akan menjadi local leader yang akan merawat dan menjaga kelestarian alam, sehingga tercipta proses pendidikan yang diberikan searah dengan potensi alam yang ada, dan setiap orang akan bangga menjadi bagian dari wilayahnya dan menjaga lingkungan sekitar agar tetap lestari.

\section{Kesimpulan}

Setiap anak membawa potensi masing-masing. Potensi atau fitrah merupakan pembawaan lahir dan merupakan anugerah bagi setaip anak. Tugas orang tua adalah menemukan dan mengembangkan fitrah yang telah ada. Berbagai fitrah yang ada dalam diri setiap manusia menjadikan manusia makhluk yang istimewa. Keistimewaan tersebut akan terlaksana manakala orang tua dan pendidik mampu menemukan dan mengembangkan fitrah anak. Dalam Al-Qur'an dijelaskan bahwa manusia membawa fitrah keimanan (QS. Al-Rûm [30] 30), 
selain itu Nabi Adam sebagai manusia pertama diberikan kemampuan untuk menyebutkan berbagai nama (QS. al-Baqarah [2] 31-32) hal ini merupakan potensi daya fikir (belajar) sehingga dengan kemampuan tersebut manusia menjadi makhluk mulia. Selain itu fitrah yang terdapat dalam diri manusia adalah fitrah bakat (Qs. Al-Isra [17] 84) dan seseorang akan berhasil dengan mudah jika melakukan aktifitas sesuai dengan fitrah bakat. Untuk menselaraskan dengan kehidupan, Allah memberikan fitrah alam, dimana terdapat banyak potensi dari alam yang dapat dimanfaatkan oleh manusia, sehingga dapat menguntungkan manusia.

\section{Daftar Pustaka}

Abdullah, Abdurrahman Saleh Teori-teori Pendidikan Berdasarkan Al-Qur'an, Jakarta: Rineka Cipta, 1990.

Alim, Akhmad Tafsir Pendidikan Islam, Jakarta: AMP Press, 2014.

Arifin, Ilmu Pendidikan Islam: Tinjauan Teoritis dan Praktis Berdasarkan Pendekatan Interdisipliner, Jakarta: Bumi Aksara, 2003.

Arifin, Muhammad Ilmu Pendidikan Islam, Jakarta: Bumi Aksara, 1996.

al-Asfahaniy, Al-Raghib. Mu'jam Mufradat al-Fadl Al-Qur'an, Beirut: Dar el-Fi$\mathrm{kr}, 1972$.

al-Bukhari, Muhammad ibn Isma'il Shahih Bukhari, juz 5, hadis nomor 1296.

Chatib, Munif Orang Tuanya Manusia: Melejitkan Potensi dan Kecerdasan dengan Menghargai Fitrah Setiap Anak, Bandung: Kaifa, 2015.

Edy, Ayah Rahasia Ayah Edy Memetakan Potensi Unggul Anak, Jakarta: Noura Books, 2015.

Gojali, Nanang Tafsir dan Hadits tentang Pendidikan, Bandung: Pustaka Setia, 2013.

Hasbullah, Dasar-dasar Ilmu Pendidikan, Jakarta: RajaGrafindo, 2012.

Hude, Darwis Logika Al-Qur'an, Jakarta: Eurobia, 2015.

al-Jurjani, Ali ibnu Muhammad At-Ta'rifat, juz 1.

Kodir, Faqihuddin Abdul, Bergerak Menuju Keadilan, Jakarta: Rahima, 2006.

Mulyasana, Dedi Pendidikan Bermutu dan Berdaya Saing, Bandung: Remaja Rosdakarya, 2012.

Munawar, Ahmad Warsono Kamus Arab Indonesia al-Munawir,

Surabaya: Pustaka Progresif, 1997.

Nata, Abuddin Pendidikan dalam Perspektif Al-Quran, Jakarta: UIN Jakarta Press, 2005.

Suwito, Sejarah Pemikiran Para Tokoh Pendidikan, Jakarta: Angkasa, 2003. Asy-Sya’rawi, Muhammad Mutawalli Tafsir As-Sya'rawi. 
Suharto, Dedhi Quranic Intelligence Quotient, Tangerang: FBA Press 2006.

Yunus, Mahmud Kamus Arab-Indonesia, Jakarta: Yayasan Penyelenggaraan Penterjemahan Tafsir Al-Qur’an, 1973.

Wahab, Wahib, Fitrah dalam Wawasan Al-Quran dan Implikasinya dalam Pembelajaran, Jakarta: Nizamia, 1998.

Al-Zamakhsyari, al-Kasysyaf 'an Haqaiq al-Tanzil wa al-'Uyun al-Aqawil fi wujuh al-Ta'wil, Beirut: Dar al-Kitab al-'Arabi, tth. 